\title{
CONTINUOUS MONITORING OF SERUM IONIZED CALCIUM IN THE DOG DURING SODIUM CITRATE INFUSION USING AN EXTRACORPOREAL BLOOD SHUNT*
}

\author{
John K. Hayes, Richard A. Bremer, K. C. Wong, William S. Jordan \\ AND DWAYNE R. WESTENSKOW
}

\begin{abstract}
The effect of sodium citrate infusion on the cardiovascular system was studied in six mongrel dogs. Serum ionized calcium concentration $\left(\left[\mathrm{Ca}^{++}\right]\right.$) was monitored continuously using a Radiometer calcium selective electrode (Selectrode) in an extracorporeal blood shunt. Twelve, 24 and $48 \mathrm{mg} \cdot \mathrm{kg}^{-1}$ of sodium citrate were infused into each animal. These concentrations correspond to the maximum amount of citrate that would be received by a $70 \mathrm{~kg}$ man given 0.5. 1.0 and 2.0 units of CPD treated blood. Each of the solutions were infused over a 5 -minute period to duplicate a fairly rapid rate of blood transfusion in man. The decrease in $\left[\mathrm{Ca}^{++}\right]$along with blood $\mathrm{pH}$ and cardiovascular parameters were measured to determine the relationship between $\left[\mathrm{Ca}^{++}\right]$and cardiovascular dynamics. The following parameters were analyzed: mean arterial pressure (MAP), heart rate (HR), stroke volume (SV), peripheral vascular resistance (PVR), cardiac output (CO), pulmonary arterial pressure (PAP), pulmonary wedge pressure (PWP). $\left[\mathrm{Ca}^{++}\right]$, total calcium (Ca) and $\mathrm{pH}$. Statistically significant decreases occurred in SV, MAP and CO. Decreases in serum $\left[\mathrm{Ca}^{++}\right]$of $7.7 \pm 1.0$ per cent, 15.4 \pm 1.9 per cent and $33.6 \pm 3.6$ per cent were observed for the 12,24 and $48 \mathrm{mg} \cdot \mathrm{kg}^{-1}$ sodium citrate solution infusions, respectively. The recovery time for the $\left[\mathrm{Ca}^{++}\right]$to reach pre-infusion levels was $7.3 \pm 0.4$ minutes, $14.3 \pm 1.6$ minutes and $21.3 \pm 1.4$ minutes, respectively, for the three solutions.

Our data show that significant degrees of hypocalcaemia and myocardial depression may accompany the infustion of citrate solutions. The degree of myocardial depression that we observed in healthy, unstressed animals was not a threat to life with the quantities of citrate we infused. However, in cases requiring larger blood transfusions, such as haemorrhagic shock or RH incompatibility, the cardiovascular system will be compromised considerably at the outset and further myocardial depression secondary to hypocalcaemia may result. The extracorporeal blood shunt proved to be a very simple, efficient and illustrative way of monitoring the level of $\left[\mathrm{Ca}^{++}\right]$continuously in the circulatory system during citrate infusion.
\end{abstract}

THE IMPORTANCE OF SERUM ionized calcium concentration $\left(\left[\mathrm{Ca}^{++}\right]\right)$has been known for some time. ${ }^{1.2}$ Its effects are well documented; on the cardiovascular system depressed myocardial contractility, shortened $P Q$ interval, slight diminution of the QRS duration and prolongation of Q-T interval ${ }^{2-7}$; on the muscular system increased skeletal muscle excitability and positive Chvostek sign; ${ }^{6.8}$ in the nervous system $\mathrm{Ca}^{++}$ influences passage of $\mathrm{Na}^{+}$through the selective sodium channels in the axonal membrane. ${ }^{6}$

John K. Hayes, B.S., Bioengineering Student; Richard A. Bremer, B.S., Medical Student; K.C. Wong, M.D., Ph.D., Professor and Chairman, Department of Anesthesiology, Professor of Pharmacology; William S. Jordan, M.D., Professor of Anesthesiology and Pediatrics; Dwayne R. Westenskow, Ph.D., Assistant Professor of Anesthesiology. Department of Anesthesiology, University of Utah College of Medicine, 50 North Medical Drive, Salt Lake City, Utah 84132, U.S.A. Reprint requests to: Dr. K.C. Wong.

*Supported by a grant from The Utah Heart Association.
Clinically, large changes in $\left[\mathrm{Ca}^{++}\right]$often occur when a large volume of citrated blood is administered over a short period of time. ${ }^{9.10}$

In our study $\left[\mathrm{Ca}^{++}\right]$was decreased in mongrel dogs by infusion of three concentrated standard solutions containing 12,24 and $48 \mathrm{mg}$ of sodium citrate per $\mathrm{kg}$ body weight. These concentrations correspond to the maximum amount of citrate that would be received by a $70 \mathrm{~kg}$ man given 0.5 , 1.0 and 2.0 units of CPD-treated blood. Each of the solutions were infused over a five-minute period to duplicate a fairly rapid rate of blood transfusion in man. The decrease in $\left[\mathrm{Ca}^{++}\right]$along with blood $\mathrm{pH}$ and cardiovascular parameters were measured to determine the relationship between $\left[\mathrm{Ca}^{++}\right]$and cardiovascular dynamics.

\section{Method}

Six untreated male mongrel dogs weighing $15.5-29.0 \mathrm{~kg}$ were used in this study. Intravenous thiopentone $20-25 \mathrm{mg} \cdot \mathrm{kg}^{-1}$ was used for induc- 
tion of anaesthesia and tracheal intubation. Anaesthesia was maintained with 1.5 per cent inspired concentration of halothane in 100 per cent oxygen. Mechanical ventilation was accomplished with a Siemens-Elema ServoVentilator Model 900B. A Siemens-Elema Model 930 carbon dioxide analyzer was used to maintain end-tidal carbon dioxide at 5.0-5.5 per cent $\left(\mathrm{Pa}_{\mathrm{CO}_{2}} 4.26-4.66 \mathrm{kPa}(32-35 \mathrm{~mm} \mathrm{Hg})\right)$. Lactated Ringer's solution, $5-8 \mathrm{ml} \cdot \mathrm{kg}^{-1} / \mathrm{hr}$, was given to the dogs throughout the study through a peripheral forelimb vein. A catheter was inserted into the femoral artery for continuous monitoring of blood pressure and periodic arterial blood sampling. A four lumen Swan-Ganz catheter was inserted through the right internal jugular vein and advanced to the pulmonary artery. These lines were connected to a Bentley Trantec Model 800 pressure transducer. A Tektronix Model 414 Dual Pass electrocardiogram (ECG) monitor/recorder was used for minitoring of ECG, heart rate (HR), mean arterial pressure (MAP) and pulmonary wedge pressure (PWP). An Edwards Model 9520 cardiac output computer was used to obtain cardiac output $(\mathrm{CO})$ values by a thermal dilution technique.

An extracorporeal blood shunt (EBS) constructed out of a solid cylinder of polymethylmethacrylate was machined to accept three Radiometer electrodes (K401 reference electrode, G2040B glass pH electrode and a F21 $12 \mathrm{Ca}$ calcium selective electrode [Selectrode]). Before the calcium selectrode and the K 401 calomel reference electrode were placed in the EBS, the electrode's distal ends were both covered with a cuprophane dialysis membrane to prevent blood protein interference. This shunt is a straight through flow device having very little peripheral resistance and a dead space of $1 \mathrm{ml}$ (Figure 1). The Calcium Selectrode was calibrated in standard solutions of $\mathrm{CaCl}_{2}$ in 0.9 per cent $\mathrm{NaCl}\left(1 \times 10^{-2} \mathrm{M}, 5 \times 10^{-4} \mathrm{M}\right.$ and $5 \times 10^{-5}$ M). The Selectrode could be calibrated either in vitro by the normal method using the above calcium standards in normal saline or in an in vivo setting with the Selectrode placed in the shunt and attached to the animal. This in vivo calibration was done at the appropriate temperature first by closing the two 3-way stopcocks (Figure 1) thus eliminating blood flow through the shunt. The shunt was then flushed with de-ionized water to clear excess blood from the lumen. Next the de-ionized water was eliminated by flushing the shunt with the appropriate calcium standard. The mv potential obtained from this calcium standard

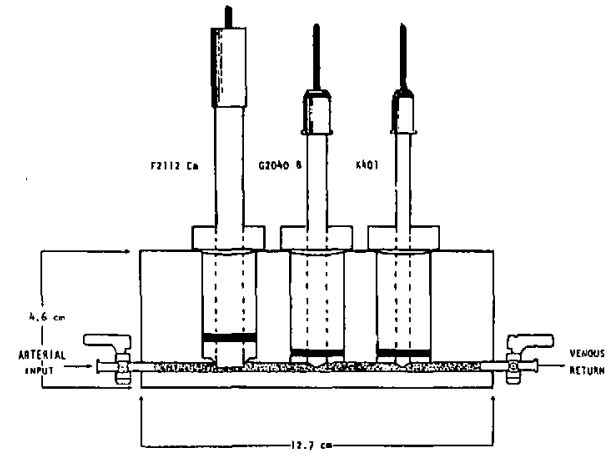

FIGURE 1 Diagrammatic representation of electrodes assembled in EBS showing height and length dimensions along with blood flow through shunt. A cuprophane dialysis membrane covered the distal ends of the Calcium Selectrode (F2112 Ca) and the calomel reference electrode (K401) to prevent blood protein interference.

was plotted on the Selectrode calibration chart which was constructed relating millivolt response (mv) to ionized calcium concentration. After this process the shunt could be flushed with the other two calcium standards and their individual mv responses entered on the Selectrode calibration chart to give a three point calibration curve. After the in vivo calibration was accomplished, the calcium standard was flushed from the lumen of the shunt with physiological saline and normal blood flow was resumed by re-opening the two 3-way stopcocks. The shunt $\mathrm{pH}$ electrode was calibrated with a $1 \mathrm{ml}$ arterial blood sample which was analyzed on a Radiometer ABL-I blood gas machine. Two digital Radiometer $\mathrm{pH}$ meters were used to monitor on-line $\left[\mathrm{Ca}^{++}\right]$and $\mathrm{pH}$ values. The outputs from these two $\mathrm{pH}$ meters were recorded on a linear chart recorder. The shunt was placed between the dog's femoral artery and femoral vein. The dogs were anticoagulated with 3,000 units of heparin per $\mathrm{kg}$ and maintained with 1,000 units $\cdot \mathrm{kg}^{-1} / \mathrm{hr}$ as needed.

Sodium citrate solutions were prepared containing 12,24 and $48 \mathrm{mg} \cdot \mathrm{kg}^{-1}$ body weight in $31 \mathrm{ml}$ of de-ionized water. The solutions were infused in random order through the peripheral forelimb vein with a Harvard infusion pump Model 975 at a rate of $6.2 \mathrm{ml} / \mathrm{min}$ over a total infusion time of five minutes. Cardiovascular parameters (ECG, HR, MAP, PWP and CO) and arterial blood samples (for serum $\left[\mathrm{Na}^{+}\right],\left[\mathrm{K}^{+}\right]$and total calcium) were obtained before each infusion and at intervals of 2, 5, 7, 10 and 20 minutes after the start of each infusion. The EBS was used for continuous monitoring of $\left[\mathrm{Ca}^{++}\right]$levels. 
TABLE I

Sodium Citrate and Its Effects on Cardovascular Parameters and Serum [Ca ${ }^{++}$]

\begin{tabular}{|c|c|c|c|c|c|c|c|}
\hline $\begin{array}{l}\text { Sodium } \\
\text { citrate }\end{array}$ & $\mathrm{CO}(1 / \mathrm{min})$ & $\operatorname{MAP}($ torr $)$ & HR & $\mathrm{SV}(\mathrm{ml})$ & $\begin{array}{c}\text { PVR } \\
(1 / \mathrm{min} / \text { tort })\end{array}$ & $\begin{array}{c}\text { Shunt }\left[\mathrm{Ca}^{++}\right] \\
(\mathrm{mmol} / \mathrm{l})\end{array}$ & Time (mins) \\
\hline Range & $(1.70-3.50)$ & $(57-110)$ & & $(15-$ & $(.0220-.0510)$ & $(0.65-1.15)$ & \\
\hline Control & $100 \%$ & $100 \%$ & $114 \pm 16$ & $100 \%$ & $100 \%$ & $0.8(100 \%)$ & \\
\hline $12 \mathrm{mg}$ & $98.7 \pm 1.9 \%$ & $95.9 \pm 1.9 \%^{*}$ & $115 \pm 17$ & $98.1 \pm 1.5 \%$ & $104 \pm 3.3 \%$ & $92.3 \pm 1.0 \% *$ & $7.3 \pm .4^{*}$ \\
\hline $24 \mathrm{mg}$ & $94.5 \pm 1.7 \%$ & $90.8 \pm 4.0 \% *$ & $115 \pm 20^{*}$ & $95.0 \pm 2.8 \%$ & $103 \pm 3.0 \%$ & $84.6 \pm 1.9 \%^{*}$ & $14.3 \pm 1.6^{*}$ \\
\hline $48 \mathrm{mg}$ & $82.9 \pm 3.3 \%$ & $81.9 \pm 4.5 \% *$ & $116 \pm 19$ & $80.2 \pm 6.3 \% *$ & $99.6 \pm 2.8 \%$ & $66.4 \pm 3.6 \%$ & $21.3 \pm 1.4^{*}$ \\
\hline
\end{tabular}

* Statistically significant, $\mathrm{p}<0.05$

All numbers represent the mean value \pm one standard deviation. $\mathrm{N}=6$.

A paired data t-test was used for statistical analysis and a probability of $p<0.05$ was considered statistically significant.

\section{Results}

Results from the infusion of 12,24 and 48 $\mathrm{mg} \cdot \mathrm{kg}^{-1}$ sodium citrate and the effects it had upon the CO, MAP, HR, SV, PVR and $\left[\mathrm{Ca}^{++}\right]$ along with the time required to eliminate sodium citrate from the dog's circulatory system can be seen in Table $\mathbf{I}$.

\section{Infusion of $12 \mathrm{mg} \cdot \mathrm{kg}^{-1}$ sodium citrate}

Serum $\left[\mathrm{Ca}^{++}\right]$began to fall 30 to 60 seconds after beginning the citrate infusion. The $\left[\mathrm{Ca}^{++}\right]$ level continued to fall throughout the infusion and reached an average minimum of $0.74 \pm$ $0.01 \mathrm{mmol}$ per litre; one standard deviation (92.3 \pm 1.0 per cent of control). The $\left[\mathrm{Ca}^{++}\right]$level began to rise soon after the citrate infusion was stopped. MAP fell to $95.9 \pm 1.9$ per cent of control. Cardiac output remained relatively constant at 98.7 \pm 1.9 per cent of control. Changes in SV, PVR, PAP, PWP and serum $\left[\mathrm{Na}^{+}\right]$and serum $\left[\mathrm{K}^{+}\right]$were not statistically significant. The blood $\mathrm{pH}$ fell an average of $0.014 \mathrm{pH}$ units during the infusion. The mean time for the return of $\left[\mathrm{Ca}^{++}\right]$to the pre-infusion value following completion of the infusion was $7.3 \pm 0.4$ minutes. As the $\left[\mathrm{Ca}^{++}\right]$ returned to normal, the other measured values also returned to their pre-infusion levels.

\section{Infusion of $24 \mathrm{mg} \cdot \mathrm{kg}^{-1}$ sodium citrate}

After infusing $24 \mathrm{mg} \cdot \mathrm{kg}^{-1}$ of sodium citrate, the $\left[\mathrm{Ca}^{++}\right]$reached an average minimum level of $0.67 \pm 0.015 \mathrm{mmol}$ per litre $(84.6 \pm 1.9$ per cent of control). Paralleling this decrease were falls in $\mathrm{CO}$ to $94.5 \pm 4.0$ per cent of control, $\mathrm{SV}$ to $95.0 \pm$ 2.8 per cent of control and MAP to $90.8 \pm 4.0$ per cent of control. Changes in PVR, MAP, PWP, $\left[\mathrm{Na}^{+}\right]$and $\left[\mathrm{K}^{+}\right]$were not statistically significant.
The blood $\mathrm{pH}$ decreased an average of 0.0184 units during the infusion. The recovery time for $\left[\mathrm{Ca}^{++}\right]$following the citrate infusion was $14.3 \pm$ 1.6 minutes. All other values returned to control levels as $\left[\mathrm{Ca}^{++}\right]$recovered.

\section{Infusion of $48 \mathrm{mg} \cdot \mathrm{kg}^{-1}$ sodium citrate}

Following the infusion of $48 \mathrm{mg} \cdot \mathrm{kg}^{-1}$ of sodium citrate $\left[\mathrm{Ca}^{++}\right]$averaged $0.53 \pm 0.03$ $\mathrm{mmol} / \mathrm{litre}(66.4 \pm 3.6 \mathrm{per}$ cent of the preinfusion value). Cardiac output, SV and MAP decreased to $82.9 \pm 4.5,80.2 \pm 6.3$ and $81.9 \pm 4.5$ per cent of control, respectively. The blood $\mathrm{pH}$ decreased an average of $0.022 \mathrm{pH}$ units during the infusion, returning to base-line after the infusion was completed. The recovery time for $\left[\mathrm{Ca}^{++}\right]$was $21.3 \pm 1.4$ minutes. The cardiovascular parameters returned to pre-infusion levels concurrently.

\section{Discussion}

Changes in total calcium were insignificant as compared to changes in $\left[\mathrm{Ca}^{++}\right]$. The changes that we observed in $\left[\mathrm{Ca}^{++}\right]$are presumably due to formation of a complex of $\left[\mathrm{Ca}^{++}\right]$with citrate. Slight decreases in $\mathrm{pH}$ which accompanied citrate infusions were much too small to account for the changes in $\left[\mathrm{Ca}^{++}\right], " 1 \mathrm{In}$ addition, there was a nearly linear relationship between the amount of citrate infused and the percentage decrease in $\left[\mathrm{Ca}^{++}\right]$. The degree of reduction in $\left[\mathrm{Ca}^{++}\right]$that we observed with citrate infusion correlates well with previously reported values for comparable doses of citrate..$^{3,12-14}$ Continuous monitoring of the $\left[\mathrm{Ca}^{++}\right]$level allowed us to observe and define the transient nature of $\left[\mathrm{Ca}^{++}\right]$depression following a citrate infusion. A typical response obtained from one of our dogs relating drops in serum ionized calcium concentration to citrate infusion and the time required for citrate to be eliminated from the animal's circulatory system can be seen in Figure 2. This response of lowering serum 


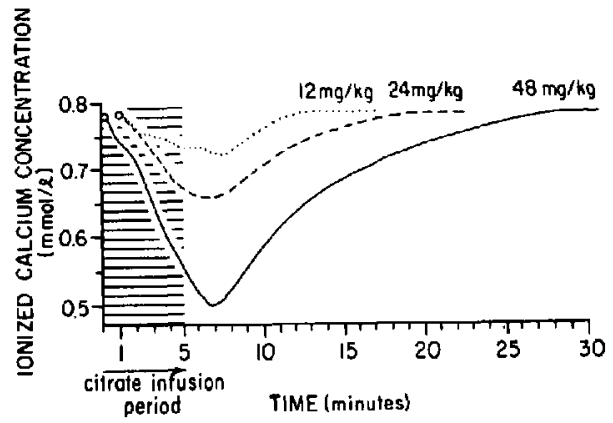

Figure 2 Typical drops in serum ionized calcium during five-minute infusions of $12 \mathrm{mg} \cdot \mathrm{kg}^{-1}, 24 \mathrm{mg} \cdot \mathrm{kg}^{-1}$ and $48 \mathrm{mg} \cdot \mathrm{kg}^{-1}$ of sodium citrate along with the time required for sodium citrate to be cleared from the dog's circulatory system.

ionized calcium concentration due to citrate infusion in this animal was similar to results obtained in other laboratory dogs during equivalent citrate infusions. Previous papers have stated that the changes were indeed brief. ${ }^{5.9 .10,14}$ Our data show the amount of $\left[\mathrm{Ca}^{++}\right]$depression that may be expected during citrate infusion and defines the time period necessary for elimination of citrate.

Our data support and verify the findings of others ${ }^{3,4,7}$ showing the importance of $\left[\mathrm{Ca}^{++}\right]$as a mediator of cardiovascular dynamics. The cardiovascular depression that resulted from decreased $\left[\mathrm{Ca}^{++}\right]$levels appeared to have a site of action mainly in the myocardium. Changes in peripheral vascular resistance were small and not statistically significant. The reduction in $\mathrm{CO}$ was due to a similar reduction in SV as HR did not vary significantly when $\left[\mathrm{Ca}^{++}\right]$levels changed. These observations correlate well with the known mechanism of action of $\left[\mathrm{Ca}^{++}\right]$as a mediator of excitation-contraction coupling in muscle beds. ${ }^{7}$ The decrease in MAP was due mainly to this decrease in CO as PVR remained constant.

Our data show that significant degrees of hypocalcaemia and myocardial depression may accompany the infusion of citrated solutions, in contrast with Kahn, et al. ${ }^{15}$ who suggest that depression of $\left[\mathrm{Ca}^{++}\right]$is devoid of clinical significance. The degree of myocardial depression that we observed in healthy unstressed animals was not a threat to life with the quantities of citrate we infused. However, in cases requiring larger blood transfusions, such as haemorrhagic shock $^{16}$ or $\mathrm{Rh}$ incompatibility, ${ }^{17}$ the cardiovascular system may be compromised consid- erably at the onset and further myocardial depression secondary to hypocalcaemia may result.

Conventional methods currently being used in establishing the level of $\left[\mathrm{Ca}^{++}\right]$within the circulatory system are: (1) drawing periodic anerobic blood samples and having them analyzed using an ion selective electrode or flame photometer or (2) monitoring the electrocardiographic tracing, noting the prolongation of the Q-T interval using the Bassett formula. ${ }^{18}$ An alternate method proposed in this paper is to monitor the level of $\left[\mathrm{Ca}^{++}\right]$continuously within the circulatory system by using a calcium ion selective electrode in an extracorporeal blood shunt.

Problems associated with periodic blood sampling involve a degree of uncertainty, especially if there are long intervals between samples, or after the infusion of large quantities of blood. ${ }^{15}$ The complete picture of the transient nature of changes in jonized calcium would not be seen with periodic blood sampling as it is with continuous monitoring using the extracorporeal blood shunt.

Likewise, problems associated with ECG monitoring arise in defining and measuring the Q-T interval from some chart recordings, especially if the $T$ wave is sloped at the onset. As observed in our study, the $\Delta Q-T$ interval from control $\left[\mathrm{Ca}^{++}\right]$levels to those of hypocalcaemic conditions were very slight and often unnoticeable from an ECG strip run at $25 \mathrm{~cm} / \mathrm{sec}$.

The EBS performed very well when placed in an in vivo setting. However, it also had problems. The major disadvantage was the need to maintain a high level of heparin within the circulatory system to prevent the initiation of blood clatting when blood components came into contact with the thrombogenic shunt. The average total level of accumulated heparin in our laboratory animals was approximately 6,000 units in a five-hour period. Electrode drift was also somewhat of a problem, but could be reduced or eliminated by periodic recalibration.

Another problem that may restrict the use of the EBS to laboratory animals is its surgical attachment. Although the EBS was not directly intended for use in patients but to illustrate and define the transient nature and levels of ionized calcium that may be present during transfusion conditions, its use in clinical situations should not be entirely ruled out since its surgical attachment is similar to an arterial-venous fistula seen in kidney dialysis patients. 


\section{SUMmaRY}

The extracorporeal blood shunt* with its ion selective calcium electrode proved to be a very simple, efficient and illustrative way of continuously monitoring the transient level of $\left[\mathrm{Ca}^{++}\right]$in the circulatory system of laboratory animals during citrate infusion. Using the extracorporeal blood shunt levels of $\left[\mathrm{Ca}^{++}\right]$could establish the hypocalcaemic state of the animal's body without using mathematical formulas or drawing numerous blood samples.

\section{ACKNOWLEDGEMENT}

The authors would like to sincerely thank Mrs. Vicky Larsen for preparation of this manuscript.

\section{REFERENCES}

1. Tepperman, J. Metabolic and endocrine physiology, 3rd edition. Chicago: Yearbook Medical Publishers, Inc. (1973).

2. GANONG, W.F. Review of medical physiology, 8th edition. Los Altos, California: Lange Medical Publishers (1977).

3. Olinger, G., Hottenrott, C., Mulder, D.G. et al. Acute clinical hypocalcemic myocardial dcpression during rapid blood transfusion and postoperative hemodialysis. J. Thorac. Cardiovas. Surg. 72: 503 (1976).

4. Rumancik. W.M., Benlinger. K.J., NahrwoLD, M.L., et al. The QT interval and serum ionized calcium, J.A.M.A. 240:366(1978).

*Additional research is being done in co-operation with the Department of Bioengineering at the University of Utah using intravascular miniature ChemFE' (chemical field effect transistor) electrodes to monitor ionized calcium, potassium and hydrogen ion activity continuously.
5. HinkLe, J.E. \& CoOperman, L.H. Serum ionized calcium changes following citrated blood transfusion in anaesthetized man. Br. J. Anaesth. 43: 1108 (1971).

6. Eyzaguirre, C. \& Fidone, S.J. Physiology of the nervous system, 2nd edition. Chicago: Yearbook Medical Publishers, Inc. (1975).

7. LANGER, G.A. Heart: excitation-contraction coupling. Ann. Rev. Physiol. 35: 55 (1973).

8. Paschkis, K.E., Rakoff, A.E., Cantarow, A., et al. Clinical Endocrinology, 3rd edition. New York: Harper and Row (1967).

9. Perkins, H.A., Snyder, M., Thatcher, C., et al Calcium ion activity during rapid exchange transfusion with citrated blood. Transfusion 11: 204 (1971).

10. Gershanik, J.J., Levkoff, A.H. \& Duncan, $R$ Serum ionized calcium values in relation to exchange transfusion. J. Ped. 82: 847 (1973).

11. Schaer. H. \& Bachman, U. lonized calcium in acidosis: differential effect of hypercapnia and lactic acidosis. Br. J. Anaesth. 48: 842 (1974).

12. Denlinger, J.K., Nahrwold, M.L., Gibas, P.S., et al. Hypocalcaemia during rapid blood transfusion in anaesthetized man. Br. J. Anaesth. 48: 995 (1976).

13. SzYmanSKI, J.O. Ionized calcium during plateletpheresis. Transfusion 18: 701 (1978).

14. Ladenson, J.H., Muller, W.V. \& Sherman, L.A. Relationship of physical symptoms, ECG free calcium and other blood chemistries in reinfusion with citrated blood. Transfusion 18: 670 (1978).

15. Kahn, R.C., Jascott, D., Carlson, G.C., el al Massive blood replacement: correlation of ionized calcium, citrate and hydrogen ion concentration. Anesth. Analg. 58: 274 (1979).

16. MCCONNELL, D. Shock: rapid transfusion, calcium levels, $\mathrm{pH}$ and body temperature. General Surgery - Epitomes 129: 130 (1978).

17. MaISELS, J.M. Li, T.K. Piechocki, J T et al. The effects of exchange transfusion on serum ionized calcium. Pediatrics 53: 683 (1974).

18. EsTES, E.H. Electrocardiology and vectorcardiology. In The Heart, by J.W. Hurst and R.B. Logue. eds. New York: McGraw-Hill Book Company Inc. (1970).

\section{RÉSUMÉ}

Six chiens de sang mêlé ont servi à l'étude du retentissement de la perfusion de citrate de soude sur le système cardiovasculaire. La concentration sérique du calcium ionisé $\left(\mathrm{Ca}^{++}\right)$a étè monitorée de façon continue avec une électrode sélective au calcium fabriquée par Radiometer (Selectrode) placée dans un shunt extracorporel. Du citrate de soude aux doses de $12,24 \mathrm{et} 48 \mathrm{mg} \cdot \mathrm{kg}^{-1}$ a été perfusé à chaque animal. Ces concentrations équivalent à la quantité maximale de citrate que reçoit un homme de $70 \mathrm{~kg}$ lorsqu'il est transfusé avec $0.5,1.0$ et 2.0 unitês de sang. Chacune des solutions a été injectée sur une période de cinq minutes de façon à imiter une transfusion rapide de sang chez l'humain. La baisse de $\mathrm{Ca}^{++}$ainsi que les paramètres acidobasiques et cardiovasculaires ont été mesurés pour déterminer la relation entre $\mathrm{Ca}^{++}$et la dynamique cardiovasculaire. Les paramètres suivants ont été analysés: la pression artérielle moyenne, la fréquence cardiaque, le volume d'éjection, la résistance vasculaire périphérique, le débit cardiaque, la pression artérielle pulmonaire, la pression capillaire pulmonaire, le $\mathrm{Ca}^{++}$, le calcium total (Ca) et le $\mathrm{pH}$. Des baisses significatives sont survenues pour le volume d'éjection, la pression artérielle moyenne et le débit cardiaque. Des diminutions dans le $\mathrm{Ca}^{++}$sérique de $7.7 \pm 1.0$ pour cent, $15.4 \pm 1.9$ pour cent et de $33.6 \pm 36$ pour cent ont été observés lors de la perfusion de 12,24 et $40 \mathrm{mg} \cdot \mathrm{kg}^{-1}$ respectivement. Le 


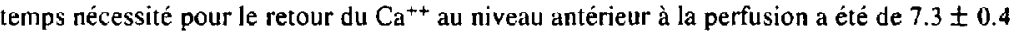
minutes, $14.3 \pm 1.6$ minutes et $21.3 \pm 1.4$ minutes respectivement pour les trois solutions.

Ces données montrent qu'un degré significatif d'hypocalcémie et de dépression myocardique peut accompagner la perfusion de solutions citratées. Le degré de dépression myocardiquc observé chez les animaux en santé et non soumis au stress $n$ 'a jamais causé de menace à la vie lors de l'injection des quantités de citrate mentionnées. Cependant, lorsque plusieurs transfusions sont requises, comme dans le choc hémorragique ou l'incompatibilité RH et que le système cardiovasculaire peut être sérieusement compromis au départ, une dépression myocardique secondaire à l'hypocalcémie peut se surajouter. Le shunt sanguin extracorporel s'est avéré un moyen simple, efficace et démonstratif de monitorer les niveau de $\mathrm{Ca}^{++} \mathrm{du}$ système circulatoire pendant la perfusion de citrate. 